\title{
Millet (Eleusine coracana) Flour Fortification in Composite Bread
}

\author{
ISHWAR SUBEDI ${ }^{1 *}$, CHRISTINA HARNISCH ${ }^{2}$, GERHARD KATER ${ }^{2}$ and TULASHI ADHIKARI ${ }^{3}$
}

\author{
${ }^{1}$ Department of Food Technology and Quality Control, Kathmandu- Nepal \\ ${ }^{2}$ Anhalt University of Applied Science, Bern burg - Germany \\ ${ }^{3}$ Institute of Medicines, Maharajgunj Nursing Campus, TU, Nepal
}

\begin{abstract}
Composite bread prepared by wheat flour (550 types, moisture 10.85\%) and millet (Eleusine coracana) flour (moisture 10.8\%) were determined to evaluate bread qualities by 2 methods. The first method included application of raw millet flour, where as the second methods included cooked (gelatinized) millet flour before baking. The breads were named as (0MB) only from wheat flour followed by (10CCMB), (20CCMB) and (30CCMB) using 10, 20 and 30\% coarse (669 $\mu$ m) cooked millet flour respectively where as (10FCMB) and (10FUMB) were named as fine $(431 \mu \mathrm{m})$ sized millet flour. The former was gelatinized where as the later wasn't. These composite breads were made from a blend of 90, 80 and 70 parts of wheat flour with 10, 20 and 30 parts of millet flour respectively. The bread with 10, 20 and 30\% composite flour were similar in crumb porosity, texture, smell and taste where as 30\% millet flour had higher dough and bread yield.
\end{abstract}

Keywords: Millet flour, Composite bread, Gelatinisation, Quality

\section{Introduction}

Bread is a nutritional, culinary, social and environmental mess and one of the mankind's important discoveries, possibly ranking alongside the discovery of fire and the invention of the wheel. Bread has played a key role in the development of mankind and is a principle source of nutrition. Historically, it has contributed to language social structuring and spiritual imagery (Cauvain and Young, 2006). Today it contributes conveniences, variety and a healthy dietary component to modern lifestyle. Since millet (Eleusine coracana) is a main food grain for many peoples, it is also being thought to fortify to wheat cereal for baking. In fact, millet is an annual plant that widely grown as a cereal in a region, where it is characterised by a severe lack of available water. It is adaptable to acrid areas such as higher elevations of Himalaya and grown up to 2,300 meters like as Nepal. Originally, it is native to the Ethiopian highlands and introduced in India approximately 4,000 years ago (Andrea et al., 1999). It is the most common cereals in Asia and Africa. Although wheat is a principle cereal used for bread making other cereal particularly millet is also being used in some extent to make cereal products such as biscuit and cakes but the result was not satisfactorily due to the lack of technological inputs. Therefore, it was expected to use millet as much as possible as a substitution to wheat flour so that composite bread with excellent quality could be obtained. The main objective of this research work was to use millet substitution in wheat flour up-to $30 \%$ for the production of quality composite bread with the optimization of the fresh holding characteristics.

\section{Materials and Methods}

The millet cultivated at Anhalt University (Germany) were cleaned, sieved, de-husked, milled (particle sized 669 and $431 \mu \mathrm{m}$ ) for coarse and fine respectively, cooked (Gelatinized) and cooled prior to mix with wheat flour (type 550). The millet

\footnotetext{
*Corresponding author, E-mail: ishwar.subedi@gmail.com
}

was milled using lab scale milling devices (Handbuch BW 1S21) which couldn't mill millet grain efficiently to powder. The physico-chemical properties of composites flour have been shown in the Table 3. The moisture was determined using hot air oven, the world standard method (AACC, 2000). Similarly, ash, to determine inorganic substances, was also determined using ICC standard based on 104/1. Sedimentation value that provides information on the protein quantity and quality of flour samples, its value can be in the range of 20 or less for low protein flour with weak gluten to as high as 70 or more for high protein with strong gluten (Paul, 2000). Sedimentation value of wheat and composite flour of wheat and millet were measured respectively using lactic acid solution during a standard time interval based on AACC, ICC No 116/1. The falling number was measured using the world standard alpha amylase activity test- AACC No. 56-81B, ICC No. 107/1, ISO/DIS 3093, ASBC. Gluten is the functional component of protein and determines processing characteristics of flour. It was measured using the ICC standard No 155 and 158, AACC method No 38-12, ISO 7495. Force or torque during mixing a small quantity of dough that characterizes quality and mixing behavior of tested flour was determined by Farinograph Units (FU) following ICC standard No. 115/1. It was important to measure percentage of water absorption, dough development time (DDT), dough stability (DS) and mixing tolerance index (TI). The recipe and process control is here by shown in the Table 1 and 2 The lab work of final product included measurement of physico-chemical properties such as water content, acid degree, compressibility, resilience and elasticity where as technological properties included dough yield, bread yield, bread volume yield and baking loss as shown in Table 4.0 The acid degree which is important to determine the physical state of gluten was measured by AACC (2000) method. Compressibility was measured in terms of texture using Penetrometer. The force was measured for 5 seconds and 115 seconds respectively which were monitored ad read by scale on the penetrometer. The difference in force $(\Delta \mathrm{Km})$ 
in 115 and 5 seconds indicated the force applied to the bread crumb $\left(\Delta \mathrm{Km}=\mathrm{Km}_{115}-\mathrm{Km}_{5}\right)$. This test was measured under the AACC, (2000) method.

Sensory analysis- The test was designed qualitatively to evaluate the goodness and badness of bread quality for the characterization and evaluation of different bread samples. The four samples of composite bread and the control were served to
10 trained panelists made up of populations of staff of Anhalt University who were familiar with the sensory attributes such as color, aroma, texture and taste of the samples. Ranking of the samples on the basis of popularity was designed to measure the degree of preference of the samples. All the data were subjected to analyze Friedman test; F Test (O’ Mahony, 1986).

Table 1. Recipe of the products

\begin{tabular}{lcccccc}
\hline & \multicolumn{7}{c}{ Type of products } \\
\cline { 2 - 7 } Ingredients & 0MB & 10CCMB & 20CCMB & 30CCMB & 10FCMB & 10FUMB \\
\hline Wheat flour (\%) & 100 & 90 & 80 & 70 & 90 & 90 \\
Millet flour (\%) & $\times$ & 10 & 20 & 30 & 10 & 10 \\
Water (\%) & 60.5 & 60.5 & 60.5 & 60.5 & 60.5 & 60.5 \\
Salt (\%) & 1.67 & 1.67 & 1.67 & 1.67 & 1.67 & 1.67 \\
Yeast & 1.33 & 1.33 & 1.33 & 1.33 & 1.33 & 1.33 \\
Sugar (\%) & 1 & 1 & 1 & 1 & 1 & 1 \\
Lecithin(\%) & 0.67 & 0.67 & 0.67 & 0.67 & 0.67 & 0.67 \\
\hline
\end{tabular}

Table 2. Process control Table

\begin{tabular}{|c|c|c|}
\hline \multirow{3}{*}{ Preparations } & Millet cooking time (Min) & 15 \\
\hline & Slow kneading time (Min) & 1 \\
\hline & Fast kneading time (Min) & 3 \\
\hline & Temp after kneading $\left({ }^{\circ} \mathrm{C}\right)$ & 35 \\
\hline \multirow[t]{2}{*}{ Primary fermentation } & Time (Min) & 15 \\
\hline & Temp $\left({ }^{\circ} \mathrm{C}\right)$ & 35 \\
\hline \multirow[t]{4}{*}{ Secondary fermentations } & Time (Min) & 50 \\
\hline & $\operatorname{Temp}\left({ }^{\circ} \mathrm{C}\right)$ & 35 \\
\hline & Step 1 -Temp $\left({ }^{\circ} \mathrm{C}\right)$ & 210 \\
\hline & Time (Min) & 10 \\
\hline \multirow[t]{4}{*}{ Baking } & Step 2 -Temp $\left({ }^{\circ} \mathrm{C}\right)$ & 200 \\
\hline & Time (Min) & 10 \\
\hline & Step 3 -Temp $\left({ }^{\circ} \mathrm{C}\right)$ & 180 \\
\hline & Time (Min) & 15 \\
\hline
\end{tabular}

\section{Results and Discussion}

The dough and bread yield were higher in 30CCMB, 20CCMB and 10FUMB due to higher water holding capacity, where as other were according to standard value as shown in figure 1.0 and 2.0 respectively. Textural property showed 10FUMB with highest elasticity where as $0 \mathrm{MB}$ with the lowest one. The resilience was around equal in all the samples. According to the sensory evaluation, the bread with 10 and $20 \%$ composite flour were similar to normal wheat bread. Coarse cooked was interesting to look and also acceptable. The overall physico-chemical properties of composite bread have been shown in Table 4.0 where the dough and bread yield were higher as shown in fig 1.0 and 2.0 Dough from $20 \%$ and $30 \%$ millet flour and so produced were harder in consistency due to poor elasticity of dough. The temperature of water was also controlled during mixing because the viscosity of dough decreases by several factors at higher temperature continuously. During the dough preparation it was observed that higher the gluten content of wheat flour, better the elasticity and softness of the dough. In the case of excess millet flour, it was supposed to less expansion of dough during fermentation due to poor availability of gluten. The granular mouth feel during taste were also experienced in $20 \%$ and $30 \%$ millet bread which could be less cohesiveness between millet and wheat flour. The fat content of millets was higher than wheat flour alone. Millet contains more calories than wheat, probably because of its higher oil content of around $4.2 \%$, the flour could be responsible for more yellow color, buttery and cream aroma. Although baking additives, lecithin as emulsifier was also added during mixing for stabilizing the fat components but it aided to reduce the fat molecules into tiny fat droplets and increases the surface areas of fat in 
dough batters and later onsets the flavor changes during high temperature baking (Stampfli and Nersten, 2000). Likely the increased crude fiber and ash contents of millet flour showed that at higher dilution levels, the coarse millet flour enhanced the fiber and ash content of the mixtures and affect the quality attributes differently. The wheat protein (Gluten) is responsible for the elasticity of the dough by causing it to extend and trap the carbon dioxide generated by yeast during fermentation (Olaoye, 2006). When gluten coagulated under the influence of heat during baking, it served as the fame work of the loaf, which became relatively rigid and did not collapse. Millet flour contained no gluten and consequently could not be used solely for bread making. When used, a limit of substitution level with wheat flour likely to be desirable. The dark color at higher millet proportion bread in compared to other low millet breads seemed to be higher availability of sugar to undergo browning reaction due to Millard and caramelization reaction.

Table 3. Physico-chemical properties of flour

\begin{tabular}{lccccc}
\hline Parameters & Wheat flour & $\begin{array}{c}\text { Millet } \\
\text { flour }\end{array}$ & $\begin{array}{c}\text { Millet } \\
\text { flour 10\% }\end{array}$ & $\begin{array}{c}\text { Millet } \\
\text { flour 20\% }\end{array}$ & $\begin{array}{c}\text { Millet } \\
\text { flour 30\% }\end{array}$ \\
\hline Moisture & 10.5 & 10 & - & - & - \\
Ash & 0.554 & 0.912 & - & - & - \\
Sedimentation & 10 & - & 9 & 10.5 & 13.5 \\
Falling number & 349.5 & - & 324.5 & 304 & 276.5 \\
Gluten index & 98.35 & - & 99.36 & 97.05 & 98.7 \\
Farinograph at 500 BU & 60.5 & - & 59.2 & 58 & 56.6 \\
\hline
\end{tabular}

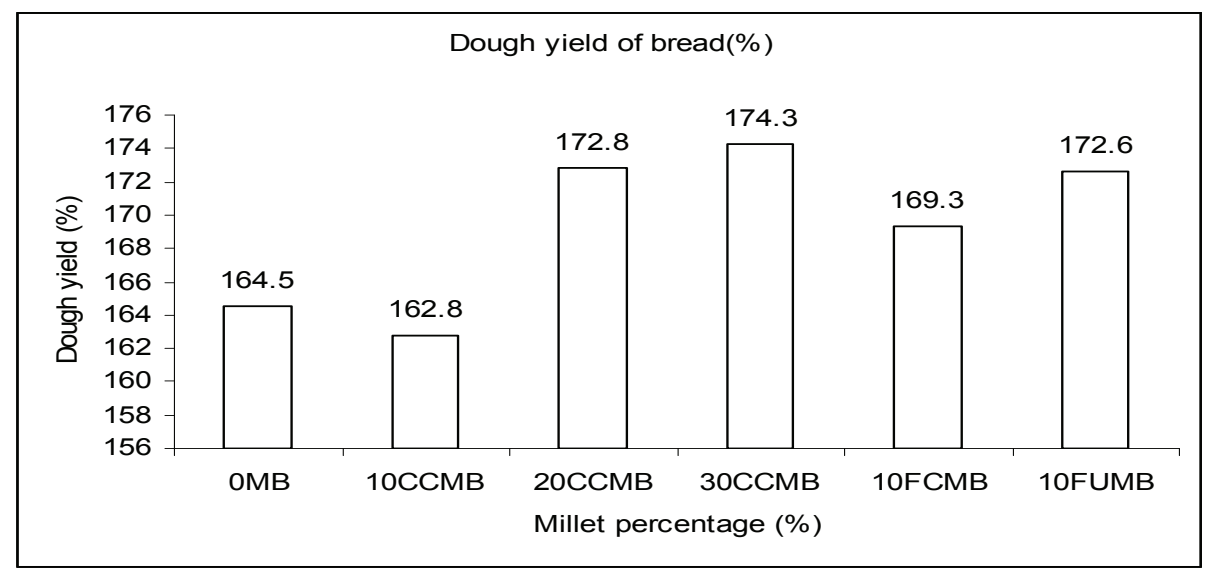

Figure 1. Dough yield of composite bread

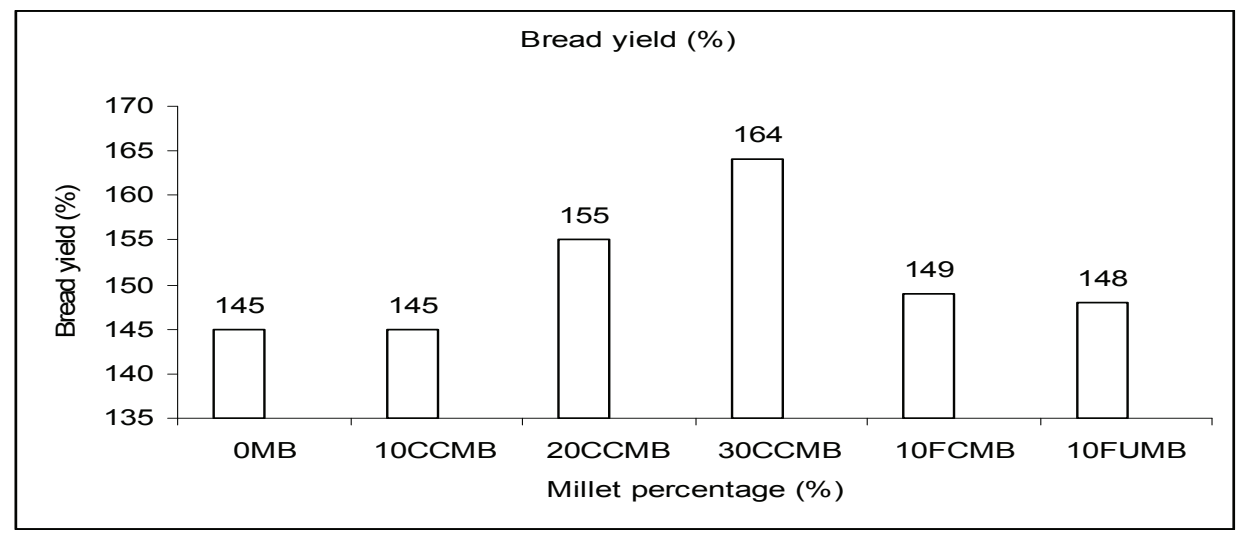

Figure 2. Yield of composite bread 
Table 4. Overall physico-chemical results of the breads

\begin{tabular}{lcccccc}
\hline & \multicolumn{7}{c}{ Samples } \\
\cline { 2 - 7 } Parameters & 0MB & 10CCMB & 20CCMB & 30CCMB & 10FCMB & 10FUMB \\
\hline Dough yield (\%) & 164.5 & 162.8 & 172.86 & 174.3 & 169.3 & 172.6 \\
Yield of bread(\%) & 145 & 145 & 155 & 164 & 149 & 148 \\
Bread volume yield (\%) & 88.1 & 89.5 & 90 & 94.1 & 88.3 & 89.1 \\
Baking loss (\%) & 11 & 11.7 & 10 & 6 & 11.6 & 11.1 \\
Acid degree(ml) & 2.8 & 3.3 & 2.6 & 2.1 & 2.9 & 2.9 \\
Water content(\%) & 42.6 & 42.1 & 44.7 & 49.9 & 43.7 & 42.9 \\
$\Delta$ Km=Km $115-\mathrm{Km}_{5}$ & 7 & 8 & 6 & 7 & 6 & 6 \\
Elasticity(\%) & 25.5 & 26.5 & 31 & 32 & 35.6 & 57.6 \\
Resilience(\%) & 76.4 & 75 & 80.7 & 75 & 77.8 & 70 \\
Maximum force (N) & 24.5 & 0.057 & 25.56 & 0.052 & 0.042 & 12.70 \\
\hline
\end{tabular}

\section{Conclusion}

In order to develop the baking science, use of millet flour (MF) substitution in wheat flour (WF), from 0 to $30 \%$ for the production of composite bread has been investigated. The coarse sized $(669 \mu \mathrm{m})$ and fine sized $(431 \mu \mathrm{m})$ millet flour were pre gelatinized (Cooked) prior to mix with wheat flour. Unlike, the fine particle sized millet flour $(431 \mu \mathrm{m})$ was none gelatinized to compare between pre gelatinized and none gelatinized breads quality. The dough and bread yield were observed higher in the $30 \%$ composite millet flour. The major sensory attributes such as aroma, crumb and its porosity, taste, texture and general acceptability expressed that addition of millet flour up to $30 \%$ was acceptable for bread making. Sensory test was designed on the basis of ranking test and pair wise test followed by the description tests. So it can be recommended that millet flour has a good potential for use as a functional agent in bakery products on account of its high water absorption capacity until $30 \%$.

\section{References}

AACC, (2000). Approved methods of the American Association of Cereal Chemists, 10th edition, The Association: St. Paul, MN.

Andrea A. C., Lyons D. E., Haile M. and Butler E. A. (1999). Ethno-archaeological Approaches to the Study of Prehistoric Agriculture in the Ethiopian Highlands. In: Van der Veen, Ed., The Exploitation of Plant Resources in Ancient Africa. Kluwer Academic: Plenum Publishers, New York.
Cauvin S. and Young L. (2006). Baked products: Science Technology and Practices, Bake Tran, High Wycombe, Bucks, UK, Blackwell publishing, pp: 156.

Olaoye O. A. (2006). Quality Characteristics of bread. African J. of Biotech., 16-24, Nigeria.

O’ Mahony M. (1986). Sensory evaluation of Food, Statistical Methods and Procedures, Department of Food Sciences and Technology, University of California, Davis, California, The United States, pp 6.

Paul M. (2000). Approved methods of American Association of Ceeal Chemists, $10^{\text {th }}$ edition, adopted from methods 56-61A

Stampfli L. and Nersten B. (2000). Emulsifiers in bread making, MATFORSK, Norwegian Food Research Inistitute, Osloveien 1, N- 1430 AS, Norway. 